\title{
COMMENTS
}

\section{SOVEREIGN RESPONSIBILITY AND THE DOCTRINE OF SACRIFICE (AUFOPFERUNGSANSPRUCH)}

The doctrine of sovereign immunity ${ }^{1}$ originated with the proposition that "there can be no legal right as against the authority that makes the law on which the right depends." Absent enabling legislation, ${ }^{3}$ this immunity persists in American law even when the injury or damage for which compensation is sought has bestowed some special benefit upon the community. ${ }^{4}$ Other sys-

${ }^{2}$ Consult Watkins, The State as a Party Litigant (1927) ; James, Tort Liabiilty of Governmental Units and Their Officers, 22 U. of Chi. L. Rev. 610 (1955) ; Symposium, Governmental Tort Liability, 29 N.Y.U. L. Rev. 1321 (1954) ; Parker, The King Does No WrongLiability for Misadministration, 5 Vand. L. Rev. 167 (1952); Symposium on Government Tort Liability, 9 Law \& Contemp. Prob. 179 (1942). An excellent series of articles by Edwin M. Borchard appears in 28 Col. L. Rev. 577, 734 (1928) ; 36 Yale L. J. 1, 757, 1039 (1926-27) ; 34 Yale L. J. 1, 129, 229 (1924-25).

"Holmes, J., for a unanimous Court in Kawananakoa v. Polyblank, 205 U.S. 349, 353 (1907). See also The Western Maid, 257 U.S. 419, 433 (1921). "The King is not only incapable of doing wrong, but even of thinking wrong; he can never mean to do an improper thing: in him is no folly or weakness." 1 Blackstone, Commentaries 254 (Bell ed., 1813). One of the roots of the theory is the feudal notion that a lord could not be sued in his own court. 1 Pollock and Maitland, History of English Law 518 (2d ed., 1911). Application of sovereign immunity in the United States has been called "an anachronistic survival of monarchical privilege." Frankfurter, J., dissenting in Kennecott Copper Corp. v. Tax Comm'n, 327 U.S. 573, 580 (1946). Yet only in one instance has the doctrine been denied effect. Chisholm v. Georgia, 2 Dall. (U.S.) 419 (1793). The Eleventh Amendment was speedily adopted to counteract that decision.

For further consideration of the bases of the doctrine in history, reasoning and policy, consult James, op. cit. supra note 1, at 611-15. Noteworthy judicial condemnations include Snyder v. Buck, 340 U.S. 15, 29 (1950) (Frankfurter, J., dissenting); Great Northern Ins. Co. v. Read, 322 U.S. 47, 59 (1944) (Frankfurter, J., dissenting) ; Welch v. TVA, 108 F.2d 95, 99 (C.A. 6th, 1939) (Hamilton, J.: "The maxim that 'the King can do no wrong' has no place in American constitutional law.") ; Kamau v. County of Hawaii, - Hawaii (1957) (Stainback, J.) ; Boxberger v. State Highway Dept., 126 Colo. 438, 250 P.2d 1007 (1952) (Holland, J.); Madison v. San Francisco, 106 Cal.App.2d 232, 253, 236 P.2d 141 (S.Ct., 1951) (Carter, J., dissenting) ; Bingham v. Board of Education, 118 Utah 582, 593, 223 P.2d 432, 438 (1950) (Wolf, J., dissenting).

${ }^{3}$ The sovereign may consent to be sued. See, e.g., Clark v. Barnard, 108 U.S. 436, 444 (1883). Consent to suit by the states is exhaustively treated in Leflar and Kantrowitz, Tort Liability of the States, 29 N.Y.U. L. Rev. 1363 (1954); The Sovereign Immunity of the States: The Doctrine and Some of its Recent Developments, 40 Minn. L. Rev. 234 (1956).

"Citizens of some "less civilized" societies have been subjected to a less severe doctrine of sovereign immunity. Thus, for example, Babylonian law provided: "If a man has perpetrated brigandage, and ... the brigand has not been taken, the man plundered shall claim before God what he has lost; and the city and sheriff in whose land and boundary the theft has taken place shall restore to him all that he has lost." Code of Hammurabi $\$ \$ 22-23$ (tr. 
tems of law provide a remedy analogous to restitution for one who has been compelled to make such a sacrifice. A recent decision of the Supreme Court of the West German Federal Republic is illustrative of this more liberal approach. ${ }^{5}$

While treating a wounded soldier at the University of Heidelberg clinic, a doctor who was championing a new method for photographing the venous system injected a radioactive substance into the soldier's blood stream for purposes predominantly experimental rather than therapeutical. The pictures were excellent, but the soldier was permanently incapacitated and sued the state of Baden-Württemberg for the expense of his support in excess of his veteran's stipend. The court allowed recovery on the ground that he had been compelled to make a sacrifice for the benefit of the community for which German law provides a remedy (Aufoperungsanspruch) not only with respect to encroachments upon property rights, but also for interferences with bodily integrity. This comment will consider the treatment this sacrifice doctrine has received under the law of Germany, France and the United States.

\section{Germany ${ }^{8}$}

The determination of the responsibility of the German State typically involves establishment of fault on the part of the officials who act in its behalf. In principle, liability attaches to the official himself where he has negligently or wilfully injured another in the performance of his duties. ${ }^{7}$ However, the

Edwards, 1921). Compare, e.g., 13 Edw. I, Stat. 2 (1285): "[F]rom Day to Day, Robberies, Murthers, Burnings, \& Theft [are] more often used than . . . heretofore. . . . Our Lord the King, for to abate the Power of Felons, hath established a pain in this Case. ... [I]f the Country will not answer for the Bodies of such manner of Offenders, the Pain shall be such, that every County, that is to wit, the People dwelling in the County, shall be answerable for the Robberies done, and also the Damages; so that the whole Hundred where the Robbery shall be done... shall be answerable for the Robberies done." Quoted in Shulman and James, Cases and Materials on Torts 53 (1952). Consult Clark v. Inhabitants of the Hundred of Blything, 3 D. \& R. 489, 491 (K.B., 1823) (purpose of such statutes was "to render the inhabitants of hundreds vigilant for their own sake as well as that of the public, by making them interested in the prevention of offences").

${ }^{5} 20$ BGH 61 (1956). A translation of the relevant portions of the opinion appears in an Appendix, at 530 infra.

${ }^{\circ}$ In the footnotes the following abbreviations are used: Weim. R. V. indicates Weimar Reichsverfassung (Weimar Constitution); RGZ indicates Entscheidungen des Reichsgerichts, in Zivilsachen (decisions of the Supreme Court of the Reich in civil matters) ; BGH indicates Entscheidungen des Bundesgerichtshofes, in Zivilsachen (decisions of the Federal Supreme Court in civil matters); Gr. G. indicates Bonner Grundgesetz (Basic Law of the West German Federal Republic); R.G.Bl. indicates Reichsgesetzblatt (Statutes at Large); B.G.B. indicates Bürgerliches Gesetzbuch (Civil Code).

${ }^{\approx} \S 839$, B.G.B. Such liability includes failure of an official swiftly to apprise himself of a change in the statute under which he acts, 156 RGZ 34, 51 (1937), unless the new legal background involves doubtful questions of law, 135 RGZ 110 (1932). The matter is discussed in Palandt, B.G.B. 719-20 (15th ed., 1956).

$\$ 839$ provides: "If the official is guilty only of negligence, he can be subjected to liability 
socially-felt need of providing a certain source of payment has found expression in Article 34 of the Basic Law of the West German Federal Republic, which provides:

If an officer, in exercising the public authority entrusted to him, violates his official obligations toward a third party, the responsibility therefor attaches primarily to the State or public body in the service of which the official stands. In case of wilful conduct or gross negligence the right of reimbursement is reserved to the State. For the claims for reparation or reimbursement the jurisdiction of the civil courts may not be precluded. ${ }^{8}$

Thus, compensation for damages caused by the fault of an official in the exercise of official duties ${ }^{9}$ is in every case to be had by legal action..$^{10}$

Fault is not, however, the only source of sovereign responsibility. German law protects the property-owner's dominion over his property, but stresses the social duties with which it is impressed. ${ }^{11}$ When the public interest requires,

only if the injured person can obtain compensation in no other way." With respect to wilful breaches of official duty, either the officer or the state may be sued, but if a judgment is entered against the state, it may require indemnity from an official who has acted wilfully or with gross negligence. With respect to negligent breaches, the official can point to the state as an alternative source of recovery and thereby escape liability. 11 RGZ 257, 266-67 (1937). Most significant is the fact that the state must in all events pay, whether or not indemnity is possible. $3 \mathrm{BGH} 94,104$ (1951). For a consideration of the advantages of this integrated structure of liability, consult Forsthoff, Lehrbuch des Verwaltungsrechts 234-35 (1950).

${ }^{8}$ This Article, very similar to $\S 131$, Weim. R. V., accomplishes several important functions. First, it establishes a uniform basis of responsibility applicable to all governmental units, including public corporations and associations. E.g., 112 RGZ 335, 338 (1926) (National Insurance Institute); 114 RGZ 220 (1926) (Church). Applicability of $\$ 131$, Weim. R. V., to the Church is exhaustively treated in Schumach, die Anwendbarkeit der beamtenrechtlichen Normen der Reichsverfassung auf die Kirchenbeamten (1933). Secondly, as suggested in the text, a reliable source of recovery is assured. Consult especially 3 BGH 94, 104 (1951) ; $163 \mathrm{RGZ} 82,88$ (1940). Thirdly, the state's claim of reimbursement against the official is provided with respect to precisely those offenses which constitute the greatest social danger, achieving a "primary assurance against official misdeeds." Von Mangoldt, Kommentar: Das Bonner Grundgesetz 213 (1953).

The German law of state liability, like the American law of municipal corporations, distinguishes between proprietary (fiskalisch) and governmental (hoheitsrechtlich) functions. The liability of the state established by Article 34 is limited to the situations where the state acts in its governmental capacity. With respect to its proprietary functions the state is liable to the same extent as a private employer in a like situation. $\$ \$ 823$ et seq., $31,89,831$, B.G.B.; Enneccerus-Lehmann, Recht der Schuldverhältnisse 938-39 (14th ed., 1954).

- The tortious conduct must be accomplished in the exercise of official duties, not just by chance during the course of employment, as while engaged in a frolic. 161 RGZ 145, 151 (1939); 159 RGZ 235, 238 (1938).

${ }^{10}$ Article 34, like its predecessor, Article 131, Weim. R. V., is a present, immediate (that is, self-executing) provision which requires no further law to make it applicable, or to provide for its execution. $167 \mathrm{RGZ} \mathrm{1,} 8$ (1941). Moreover, it makes inapplicable all other liability laws so far as they are inconsistent with it. Gr. G., \$31. See 102 RGZ 166, 170 (1921).

"Article 14 of the Basic Law provides: "(1) Property and inheritance are guaranteed. The content and boundaries thereof are to be fixed by legislation. (2) Property involves 
unrestricted use of private property must give way. ${ }^{12}$ However, when one individual or a delimited group of individuals ${ }^{13}$ has been called upon to benefit the community by relinquishing some interest so tangible that it can be classified as a property right, ${ }^{14}$ fair compensation must always be made. This sacrifice doctrine finds expression in Sections 74 and 75 of the Introduction to the General Land Law for the Prussian State. ${ }^{15}$ Though these provisions have no statutory authorizaiton outside the realm of Prussian property law, they have nevertheless served as a vehicle for the expansion of the "sacrifice doctrine" (Aufopferungsanspruch) they contain. By a holding that these sections are declaratory of the customary law (Gewohnheitsrecht), ${ }^{16}$ their territorial ambit has been expanded to all Germany. The truly striking aspect of this expansion is the ruling that the customary law expressed in these sections required recompense not only with respect to property encroachments but also for per-

duties. Its use shall serve the welfare of the community. (3) Condemnation is permissible only to promote the welfare of the community. It may be accomplished only through a law or pursuant to a law which provides the nature and extent of compensation. Compensation is to be measured pursuant to judicious weighing of the interests of the community and the condemnee. Due to the extent of compensation in case of contest, recourse to the ordinary courts is preserved." Consult also $\$ \$ 903$ et seq., B.G.B.; Enneccerus, Wolff and Raiser, Sachenrecht 5 (10th ed., 1957); Forsthoff, op. cit. supra note 7, at 247 et seq.

${ }^{12}$ Consult authorities cited note 11 supra.

${ }^{13}$ With respect to when the size of a group adversely affected is so large that no claim will be heard, it has been suggested that the property owners of an entire city or the riparian owners of the length of a stream would be too large. Forsthoff, op. cit. supra note 7 , at $251 \mathrm{n}$. 2. It seems obvious that when the property interests of the community as a whole are affected, as, for example, in currency reform, no claim for compensation will arise. Compare, for a similar result under American law, Norman v. Baltimore \& Ohio R. Co., 294 U.S. 240 (1935) ; Perry v. United States, 294 U.S. 330 (1935).

${ }^{1 s}$ Pure chances are not protected. For example, lowering of the level of a stream may injure possible future business activities of riparian owners and fishermen, just as the building of a new street may reduce the business of shopkeepers on the old street. Such interests are not deemed property rights in German law and therefore no claim for compensation arises with respect to such an encroachment. 139 RGZ 177 (1933); 129 RGZ 146 (1930); 101 RGZ 292 (1921). The American rule is similar. E.g., Bacich v. Board of Control, 128 P.2d 191 (Cal. App., 1942). While this state of the law gives rise to serious losses which remain uncompensated, the German courts have been active in expanding the concept of "rights." E.g., 145 RGZ 107 (1934). Also, there is a "police power" concept under which police authorities may order a building pulled down which the owner has allowed to deteriorate. Forsthoff, op. cit. supra note 7, at 247. But cf. R.G.Bl. 519 (1909).

${ }^{15}$ These sections, enacted June 1, 1794, are still in effect. 20 BGH 61 (1956); 145 RGZ 107 (1934). They provide: "Individual rights and privileges of the members of the State must yield to the right and duty of furthering the general welfare, when there is an actual contradiction or collision between the two. However, the State is required to compensate anyone from whom his special rights and privileges have had to be withdrawn for the benefit of the community."

${ }^{18} 20$ BGH 61, 68 (1956), translated in Appendix at 530 infra. See also 145 RGZ 107, 109 (1934). 
sonal injuries the suffering of which constitutes a benefit to the community. ${ }^{17}$ Moreover, as the principal case indicates, the benefit to the community resulting from plaintiff's sacrifice may be intangible indeed. ${ }^{18}$

The German courts have applied the doctrine of sacrifice only where the encroachment has been pursuant to $\mathrm{law}^{19}$ and still require that the injury be traceable to a premeditated governmental act as evidenced, for example, by a statute, regulation, or army order. Thus, in cases where no fault exists and the encroachment is not pursuant to law, ${ }^{20}$ the German courts rely heavily upon strained constructions in order to effectuate relief within pre-existing legal categories. ${ }^{21}$

The German case law indicates there is little likelihood that an all-pervasive doctrine of absolute liability with respect to dangerous activities of the State will develop. ${ }^{22}$ Nor does the German law contain a general concept of the government as an insurer with respect to its activities such as exists under the law of France. ${ }^{23}$

${ }^{17}$ Tbid. Benefit to the community arising out of the fact of the injury must be carefully distinguished from benefit arising out of the activity which caused the injury. Only the former, where there is no benefit without the injury, is properly denoted sacrifice in German law. Liability based on the latter type of benefit, where there is a benefit despite the injury, would be so broad as to include any injury caused by governmental activity since such activity, merely by reason of the fact it is engaged in, is presumably of benefit to the community. Consult discussion of French law at 520 infra. Thus, for example, in the principal case liability was imposed not so much because it was desirable to find out whether the technique would work as to determine whether this method was such as could be applied non-injuriously to human beings.

Sections 74 and 75 had earlier been applied to interests which were not strictly property. 102 RGZ 390 (1921) and 79 RGZ 427 (1912) (unregistered patents).

${ }^{28} 20$ BGH 61 (1956), translated in Appendix at 530 infra. See also the so-called Impfschadenentscheidung, 9 BGH 83 (1953) (benefit to community when party injured in compulsory vaccination).

${ }^{10} 20$ BGH 61, 63 (1956).

${ }^{20}$ For example, a policeman pursuing a criminal fires and strikes a third person who steps into the street just as the weapon is discharged. This constitutes a so-called schuldlos rechtswidriger Tatbestand. Forsthoff, op. cit. supra note 7, at 255-59. Article 839 requires fault and the doctrine of Aufopferungsanspruch requires action pursuant to law.

27 Thus, in one case, the court found a rather far-fetched implied contract to reimburse, and applied $\$ 662$, B.G.B. A policeman requested a civilian to guard a prisoner while he made a telephone call. The prisoner killed the civilian. The court held that the request and acceptance raised a contract, an implied term of which was to insure the civilian's life, for he would not have undertaken this dangerous duty unless he knew that his family would be taken care of in the event of his death. [1927] Juristische Wochenschrift 441. The court's theory of relief is criticized in Forsthoff, op. cit. supra note 7, at 261-62. Compare 167 RGZ 89 (1941) (application of $\$ \$ 844-45$, B.G.B.).

${ }^{2}$ However, some of the writers advocate development of such a doctrine (Gefährdungshaftung). E.g., Forsthoff, op. cit. supra note 7, at 259-62.

${ }^{23}$ Within a narrow area, damage flowing from riots and war, there is an exception. See Enneccerus-Lehmann, op. cit. supra note 8, at 960-62, discussing the Reichstumultschadengesetz and the Bundesversorgungsgesetz. 


\section{France $^{24}$}

In French law the sacrifice doctrine is being carried to its logical extreme and comprehends, regardless of fault, most injuries traceable to governmental activity. Although liability for sacrifice in the narrow sense of an injury which itself confers a benefit upon the public is recognized, ${ }^{25}$ this expansion of French sovereign responsibility has largely been accomplished within the category of liability for fault. ${ }^{26}$ In order that the public for which governmental functions are performed can share in the expense of their performance the doctrine of sovereign immunity has been discredited and the State is becoming an insurer with respect to the citizens it injures.

At least until 1870 , it was established law that the State was not liable to its citizens for damages flowing from faulty operation of public services. ${ }^{27}$ Thereafter, a complete volte-face in the law of sovereign responsibility was begun through extension of the rule which required compensation for a taking of private property to cover impairment of intangible property interests. And, by analogy to this expanding concept, suits for personal injuries based upon fault were increasingly permitted. ${ }^{28}$ Authorization for this development was

${ }^{23}$ This discussion of French law is based primarily on secondary material, including: Schwartz, French Administrative Law and the Common Law World 255-303 (1954); Street, Governmental Liability (1953) (passim); Jacoby, Federal Tort Claims Act and French Law of Governmental Liability: A Comparative Study, 7 Vand. L. Rev. 246 (1954); Schwartz, Public Tort Liability in France, 29 N.Y.U. L. Rev. 1432 (1954).

${ }^{25}$ E.g., Société des Produits Laitiers "La Fleurette," Council of State, January 14, 1938, discussed in text at note 36 infra.

${ }^{29}$ Schwartz, French Administrative Law and the Common Law World 255-303 (1954).

zo "If [the citizen] wanted to sue the public officer who had ordered or committed the illegal or tortious act, he was met with a dismissal because of Article 75 of the Constitution of the year VIII. ... If he wanted to sue the State . . . as a moral person responsible for its acts . . the Council of State dismissed again, this time on a theory analogous to that of force majeure. It was the established law that the State was not liable to private citizens. The damage suffered from the faulty working of public services was a risk they had to run. They had to endure the possibility of lapses, to pay this premium for lapses, in return for the services, the benefits of all sorts, that they obtained from the administrative organization of the nation and the exercise of public authority." Conclusions in Lemonnier, Council of State, July 26, 1918, quoted in Schwartz, op. cit. supra note 25, at 268-69. Compare the language of a recent New York decision: "This unfortunate and tragic incident [shot in abdomen by escaped lunatic], and others like it, are a part of the risks a community must bear." Staruck v. County of Otsego, 285 App.Div. 476, 478, 138 N.Y.S.2d 385, 387 (1955). Consult also Petroleum Co. v. Public Service Commission, 304 U.S. 209, 222 (1938).

ss "If we admit that when private property is involved the doctrine of irresponsibility must give way, it can be strongly argued that it should do likewise whenever a private individual is injured in his person and, generally, in his rights other than the right of property." 3 Duguit, Traite de Droit Constitutionnel 466 (3d ed., 1921). The change "occurred without the aid of statute; it was wholly the work of the judge." Odent, Cours de Contentieux Administratif, quoted in Schwartz, op. cit. supra note 26, at 271. That the Supreme Court of the United States is not disposed similarly to expand sovereign responsibility for takings is demonstrated by the recent case of United States v. Twin City Power Co., 350 U.S. 222 (1956), criticized in Valuation in Condemnation: The Twin City Power Case, 24 U. of Chi. L. Rev. 370 (1957). 
found by the Council of State in Article 13 of The Declaration of the Rights of Man, which proclaims that the "common contribution ... indispensable ... for the expenses of administration" must be "equally divided among all citizens, in accordance with their capacities."

Today, not only can the State be sued, but the extent of governmental responsibility is very comprehensive indeed. ${ }^{29}$ Whenever improper functioning of an administrative service injures someone, the central treasury must respond. If an official is guilty of an intentional tort, faulty supervision is indicated and the State must pay the damages ensuing from its misfeasance. ${ }^{30}$ Since it is also thought that omission of a measure which should have been taken is as blameworthy as a positive act, liability may be imposed for administrative nonfeasance such as neglect or refusal to enforce a statute or regulation. ${ }^{31}$ And the duty imposed upon the administration to act with reasonable diligence requires payment of damages when injury results from excessive tardiness in executing the law. ${ }^{32}$ Finally, the State is absolutely liable with respect to any of its activities involving "exceptional risks,"33 and this doctrine is being extended to include most injuries arising in the course of ordinary governmental activity. ${ }^{34}$

The doctrine of governmental responsibility has been carried to such lengths

${ }^{\approx}$ Schwartz, op. cit. supra note 26 , at 276-83.

${ }^{30}$ Schwartz, Public Tort Liability in France, 29 N.Y.U. L. Rev. 1432, 1440 (1954).

${ }^{31}$ In France "the exercise of authority is not a privilege, but a duty imposed upon the administration." Duez, La Responsabilité de la Puissance Publique 29 (2d ed., 1938), quoted in Schwartz, op. cit. supra note 26, at 279. Thus, in the Couitéas case, Council of State, November 30,1923, plaintiff secured the French equivalent of a judgment of ejectment against certain Tunisian natives who had established themselves on his land, but for political reasons the authorities refused to execute it. The Council of State held that although the administration might refuse to act in order to preserve the peace, the inaction was a breach of duty entailing the obligation to make plaintiff whole. Consult other cases collected in Schwartz, op. cit. supra note 26, at 280-81. Compare the position of American industrial proprietors in the mid-thirties, whose plants were seized by sit-down strikers. While the owners could obtain judgments of eviction, they were rarely enforced, and it was never contended that the State might be liable for the non-feasance.

${ }^{35}$ The most striking example of such liability was the Brunet decision, Council of State, July 18, 1919, discussed in Schwartz, op. cit. supra note 26, at 282. A minor enlisted in the Foreign Legion without parental consent. The enlistment was void and immediate discharge after the authorities were apprised of the facts was mandatory. After the father requested the son's release, several months elapsed, and due to this administrative tardiness the son was killed in combat. It was held that this delay constituted a fault for which the State was liable.

${ }^{33}$ Schwartz, op. cit. supra note 26, at 297. Professor Schwartz lists numerous examples of liability for the use of "dangerous instruments or means of action." E.g., Lecomte, Council of State, June 24, 1949 (firearms) ; Capot et Denis, Council of State, July 9, 1948 (automobiles).

"Now the Council of State can say: "[Administrative action] has made the plaintiff company suffer in the general interest individual damage that cannot be regarded as an expense normally falling upon it, and for which it is justified in demanding pecuniary reparation." Société Boulanger, November 21, 1947, discussed in Schwartz, op. cit. supra note 26 , at 297 . 
that cases have held the State liable for losses it imposes in the exercise of the highest attribute of sovereignty-lawmaking. ${ }^{35}$ In Société des Produits Laitiers "La Fleurette"36 the manufacturer of a non-injurious substitute for cream recovered the damages it sustained from a statute which prohibited the use of such products in order to protect the French dairy industry. Though the law made no provision for those injured, the Court stated:

[I]t cannot be thought that the legislator intended to impose upon the plaintiff a burden that does not normally fall upon him; and ... this burden, imposed in the general interest, must be borne by the community as a whole. ${ }^{37}$

Mr. Justice Holmes long ago admitted that the State "might conceivably make itself a mutual insurance company against accidents" and thus "distribute the burden of its citizens' mishaps among all its members." ${ }^{\prime 38}$ Precisely that is being accomplished in France with respect to losses traceable to governmental activity. The Council of State seems to be administering a scheme of social insurance supported by the common fund of the central treasury; premiums are paid by the citizens in the form of taxes for the benefit of those injured. The liability of the State is based upon risk rather than on fault.

\section{United States}

The doctrine of sovereign immunity has been applied so rigorously in the United States that, save where the legislature has intervened, an individual who has been injured by governmental action is probably without a remedy against the government. ${ }^{39}$ This is strong medicine where the public has benefited from the injury. In both German and French law this element of benefit or "sacrifice" for the general welfare is one predicate for State liability. In American law there has been no distinct legal concept of sacrifice, ${ }^{40}$ but the doctrine travels incognito through the common law.

Where injury to one is coupled with benefit to another, there may be a remedy in contract (express or implied-in-fact), tort, or quasi-contract. In a contract action the presence or absence of benefit has no special significance.

${ }^{35}$ In the United States risk of injury resulting from passage of a statute is felt to be part of the burden of living under government. See Petroleum Co. v. Public Service Commission, 304 U.S. 209, 222 (1938).

${ }^{36}$ Council of State, January 14, 1938; Schwartz, op. cit. supra note 26, at 293.

${ }^{37}$ Société des Produits Laitiers "La Fleurette," Council of State, January 14, 1938. Schwartz, op. cit. supra note 26, at 299-303, discusses the limitations of the doctrine.

${ }^{38}$ Holmes, The Common Law 96 (1881). See also 2 Harper and James, The Law of Torts 759-84 (1956); Ehrenzweig, Negligence Without Fault (1951); Borchard, Convicting the Innocent 391 (1932).

${ }^{s 0}$ Consult authorities cited note 1 supra.

${ }^{10} 38$ Words and Phrases 8 (1940) contains but one paragraph about the word sacrifice, and it is there used in connection with the admiralty doctrine of general average. 
Similarly, in a tort action benefit to the tortfeasor is quite irrelevant. While the basis of liability in quasi-contract is benefit to one party, the amount of the recovery is limited to that benefit. ${ }^{41}$ Sacrifice is a quasi-contractual right with a delictual measure of damages; the liability is based on benefit, but the recovery is measured by the injury to the sacrificor.

Probably because established tort, contract, and quasi-contract remedies ordinarily provide adequate relief, there are few situations in American law where the doctrine of sacrifice appears. But where the usual liability is excused, the existence of a benefit to the party in whose interest the loss has been inflicted has given rise to what amounts to an action for sacrifice in order to make good the damage caused. The admiralty rule of general average requires the owners of property which has been preserved from imminent peril by a deliberate sacrifice of other property to bear their ratable share of the loss. ${ }^{42}$ And the common law has required one who has trespassed on the property of another in order to save himself or his property from a grave emergency to make good the damages caused, although the technical tort of trespass is said to be excused by the circumstance of necessity. ${ }^{43}$

While the overwhelming weight of authority, ${ }^{44}$ absent a special statute, ${ }^{45}$ denies compensation to a party whose sacrifice has benefited the community

¿1 Woodward, Quasi Contracts 4-5 and passim (1913) ; Corbin, Quasi-Contractual Obligations, 21 Yale L. J. 533 (1912). But cf. Vickery v. Ritchie, 202 Mass. 247, 88 N.E. 835 (1909).

$\therefore$ Robinson, Admiralty c.16 (1939).

" Vincent v. Lake Erie Transportation Co., 109 Minn. 456, 124 N.W. 221 (1910); 1 Harper and James, op. cit. supra note 38, at 43-50, 60-64 (1956) ; Prosser, Torts $\$ 22$ (1955). Where no actual damage results, since the tort is excused, no damages are assessable. E.g., Irwin v. Yeager, 74 Iowa 174, 37 N.W. 136 (1888) (traveler may avoid obstruction in highway by trespassing on adjoining land); 1 Harper and James, op. cit. supra note 38, at 43-45. Cf. Ploof v. Putnam, 81 Vt. 471, 71 Atl. 188 (1908) (liability of owner who expelled a privileged trespasser). But cf. McKell v. Spanish Fork City, - Utah 2d -, 305 P.2d 1097 (1957) (recovery denied property owner in suit against town and neighbors who had erected dike which increased damage to plaintiff caused by unusually severe flood), and cases there cited. Consult also Bohlen, Incomplete Privilege to Inflict Intentional Invasions of Interests of Property and Personality, 39 Harv. L. Rev. 307 (1926).

"The cases are collected in 1 Harper and James, op. cit. supra note 38, at 46-48; Prosser, Torts $\$ 22$ (1955); Hall and Wigmore, Compensation for Property Destoyed to Stop the Spread of a Conflagration, 1 III. L. Rev. 501 (1907). To the foregoing should be added: Cf. Juragua Iron Co. v. United States, 212 U.S. 297 (1909) (destruction by soldiers to prevent the spread of a disease); see United States v. Caltex, Inc., 344 U.S. 149, 154 (1952).

15 There are seven such statutes: Ga. Code Ann. (1937), $\$ 88-401$; Ind. Stat. Ann. (Burns, 1950), \$48-6117; La. Civil Code (West, 1952), \$672; Mass. Laws Ann. (1952) c.48, \$5; Me. Rev. Stat. (1954), c.97, \$9; Tex. Stat. (Vernon's, 1953), \$1070; Va. Code (1950), $\$ \$ 27-20$ to $27-22$. The Georgia statute is typical: "Analogous to the right of eminent domain is the power from necessity ... to interfere with and sometimes to destroy the private property of the citizen for the public good. . . . In all such cases, any damages accruing to the owner from such acts, and which would not otherwise have been sustained, must be paid by such municipal corporation or county." 
as a whole, ${ }^{46}$ a few decisions have seen in the benefit conferred on the community a justification for compensating the injured party for his loss. One court required that a person whose property had been destroyed to prevent the spread of a conflagration be compensated by the benefited community on the grounds of an implied assumpsit. ${ }^{47}$ In another decision owners of cholerainfested goods were granted recovery against municipal officers "for the sacrifice [burning] of their property in order to save the community from a possible pestilence," ${ }^{48}$ although the trespass was excused. Finally, there is a dictum by a famous justice concerning emergency situations where private property is taken for use by military authorities or destroyed to prevent its falling into the hands of the enemy: "Unquestionably, in such cases, the government is bound to make full compensation to the owner; but the officer is not a trespasser." 49 The Supreme Court has recently held, however, that destructions necessary during wartime military operations are not compensable since the government is merely the instrument in imposing a loss attributable "solely to the fortunes of war." ground that they "involved equipment which had been impressed by the Army for subsequent use by the Army,"52 thus indicating the possibility of a liability if a benefit is involved.

The foregoing examples indicate that in limited circumstances the American law does contain a liability distinct from tort, contract or quasi-contract

${ }^{48} \mathrm{~A}$ striking argument can be made that innocent parties wrongly convicted of crimes have conferred a benefit upon the public. It is clearly socially imperative to apprehend criminals and, since it is impossible to avoid catching a few innocents while pursuing the guilty, the public benefits at the expense of those wrongly convicted. Therefore the public ought to make an equitable recompense "proportioned to the material and moral injury ... suffered by the erroneous conviction." Code of Criminal Procedure of Neuchâtel, Switzerland, $\$ 508$, quoted in Borchard, op. cit. supra note 38, at 401 (1932). Professor Borchard also quotes several state statutes providing administrative relief (ibid., at 415-17), and recounts numerous examples of special legislative dispensations (ibid., at xxiv).

${ }^{47}$ Bishop v Mayor of Macon, 7 Ga. 200 (1849). See Mayor of New York v. Lord, 18 Wend. (N.Y.) 126 (1837) (no recovery under special statute because destruction would have followed in any event), where this noteworthy dictum appears: "[T]hose for whose supposed benefit the sacrifice was made, ought in equity and justice to make good the loss which the individual has sustained for the common benefit of all. It is upon this great principle of natural equity that maritime contributions are founded." The overwhelming weight of authority is to the contrary. Consult authorities cited note 44 supra.

${ }^{2}$ Jarvis v. Pinckney, 3 Hill (S.C.) 123, 140 (1836). But cf. Juragua Iron Co. v. United States, 212 U.S. 297 (1909).

${ }^{10}$ Taney, C. J., in Mitchell v. Harmony, 13 How. (U.S.) 115, 134 (1851). See also United States v. Russell, 13 Wall. (U.S.) 623, 627-28 (1871). But see United States v. Pacific R. Co., 120 U.S. 227, 239 (1887).

${ }^{\text {to }}$ United States v. Caltex, Inc., 344 U.S. 149, 155 (1952).

ar First two cases cited note 49 supra.

62 United States v. Caltex, Inc., 344 U.S. 149, 153 (1952). "[This property] was destroyed, not appropriated for subsequent use." Tbid., at 155. 
which is the equivalent of the Aufopferungsanspruch doctrine of German law and may here properly be termed "sacrifice." When such a claim is asserted against the national and state and, to a lesser extent, municipal governments, however, it is met with the obstacle of sovereign immunity. Though derived from the common law, this immunity has found expression in the national ${ }^{53}$ and in several state constitutions. ${ }^{54}$ While it may be contended that sovereign immunity is subject to the express command of the Fifth Amendment, "nor shall private property be taken for public use without just compensation," so that an action could be maintained without legislative authorization, ${ }^{55}$ by the generally accepted view the government is subject to suit only when the legislature so provides. ${ }^{56}$ With respect to the federal government the most significant of these legislative dispensations have been the Tucker Act ${ }^{57}$ and the Federal Tort Claims Act. ${ }^{58}$

The Tort Claims Act was initially hailed as an overdue revocation of the

5 The Eleventh Amendment provides: "The Judicial power of the United States shall not be construed to extend to any suit in law or equity, commenced or prosecuted against one of the United States by Citizens of another State, or by Citizens or Subjects of any Foreign State." Not until 1890 did the Supreme Court definitively extend immunity to the states with respect to suits by their own citizens. Hans v. Louisiana, 134 U.S. 1 (1890). Of course, the judicial power extends to suits against states by other states, and comprehends jurisdiction of suits by the United States against a state. United States v. Texas, 143 U.S. 621 (1892). Further, petition for a writ of error to review a judgment or decree of a state court does not constitute a suit against a state in contravention of the Eleventh Amendment. Cohens v. Virginia, 6 Wheat. (U.S.) 264,405 et seq. (1821).

ss Ala. Const. Art. 1, $\$ 14$; Ark. Const. Art. 5, \$20; Ill. Const. Art. IV, $\$ 26$; W.Va. Const. Art. VI, \$35. Consult also Tenn. Code Ann. \$20-1702 (1955). For a general discussion of the sovereignty of the states and smaller governmental units, see James, op. cit. supra note 1 , at $615-34$, and authorities there cited. The common law of immunity for such units is traceable to Russell v. The Men Dwelling in the County of Devon, 100 Eng. Rep. 359 (K.B., 1788). For an effective indictment of the doctrine with respect to its application to smaller units, see Kamau v. County of Hawaii, - Hawaii - (1957).

"So strongly entrenched in the judicial mind is the principle of immunity in tort that legislative consent to suit, though granted in the broadest Janguage, has been deemed to exclude liability for tort." Kamau v. County of Hawaii, - Hawaii - , - (1957). See Maloney v. State, 207 Misc. 894, 900, 141 N.Y.S.2d 207, 215 (Ct.Cl., 1955). Some statutes provide judicial review for all claims. E.g., Wash. Rev. Code (1951) \$4.92.010. Yet "claims" has been equated with contract actions. See Wiseman v. State, 98 N.H. 393, 396-97, 101 A.2d 472, 475 (1953); Trempeleau County v. State, 260 Wis. 602, 604-605, 51 N.W.2d 499, 500 (1952).

${ }^{\star}$ See Black, J., dissenting in United States v. Causby, 328 U.S. 256, 271 (1946) ("absolute constitutional right to relief not subject to legislative change ...").

${ }^{56}$ See, e.g., United States v. Griffin, 303 U.S. 226, 239 (1938) ; Lewis v. State, 96 N.Y. 71, 74-75 (1884); Waterman, One Hundred Years of a State's Immunity from Suit, 14 Tex. L. Rev. 135 (1936); authorities cited note 1 supra. Consent to suit must be clearly shown. See, e.g., Malman v. United States, 207 F.2d 897 (C.A. 2d, 1953) ; Kuhnert v. United States, 127 F.2d 824 (C.A. 8th, 1942).

${ }^{57} 10$ Stat. 612 (1855), as amended, 28 U.S.C.A. $\$ 1346$ (1950).

एक 60 Stat. 843 (1946), as amended, 28 U.S.C.A. $\$ \$ 2674,2680(1950)$. 
anachronistic and unjust doctrine of sovereign immunity so far as it applies to the federal government. ${ }^{59}$ It begins with the laudable statement:

The United States shall be liable ... in the same manner and to the same extent as a private individual under like circumstances. ${ }^{60}$

But the Act proceeds to enumerate so many exceptions to this principle ${ }^{61}$ that it effectively abrogates sovereign immunity only within a narrow area. ${ }^{62}$ Whatever application the Act might have had in allowing an action for sacrifice is probably precluded by the blanket exception of all intentional torts. ${ }^{63}$

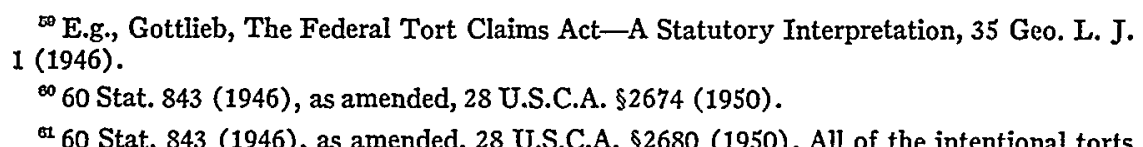
are excepted, and denial of relief in many such cases is strongly evocative of indignation. E.g., Stepp v. United States, 207 F.2d 909 (C.A. 4th, 1953) (civilian shot and killed by dock sentry). It is also provided that. no liability results with respect to acts committed in executing a statute or regulation, though invalid, or for acts within the "discretionary function or duty" of an employee or agency "whether or not the discretion involved be abused." The cases are gathered in Parker, The King Does No Wrong-Liability for Misadministration, 5 Vand. L. Rev. 167 (1952); The Discretionary Function Exception of the Federal Tort Claims Act, 66 Harv. L. Rev. 488 (1953). Parker concludes that "minor infractions committed by Government employees may be vindicated but not major ones." Parker, op. cit. supra, at 173. For a recent decision concerning the defense of discretion under state law, see St. George v. State, 283 App. Div. 245, 248, 127 N.Y.S.2d 147, 150 (1954). There are also indications that another exception is operative when an individual would be incapable of engaging in the activity which gives rise to the injury. See, e.g., Eastern Airlines v. Union Trust Co., 221 F.2d 62, 74 (C.A. D.C., 1955). But cf, Indian Towing Co. v. United States, 350 U.S. 61 (1955). Many activities of lesser significance are excepted, such as liability for negligent transmission of the mail, and the like. And the courts have been assiduous to read other exceptions into the Act. Thus, there seems to be no governmental liability for torts based on strict liability, although they are not specifically excepted. See Rayonier Inc. v. United States, 225 F.2d 642, 648 (C.A. 9th, 1955), rev'd on other grounds, 352 U.S. 315 (1957); Dalehite v. United States, 346 U.S. 15, 44 (1953). Cf. Toledo v. United States, 95 F.Supp. 838 (D. P.R., 1951) (diseased tree used for "experimental purposes" fell on plaintiff's car; recovery barred by discretionary function exception without mentioning absolute liability). But cf. United States v. Praylou, 208 F.2d 291 (C.A. 4th, 1953) (recovery under state statute imposing strict liability for damages caused by airplane crash). Similarly, soldiers who are injured while at their post or station are relegated to the veterans' legislation, for to entertain their claims has been thought to be violative of the established policy and intent of Congress. Knecht v. United States, 144 F.Supp. 786 (E.D. Pa., 1956), and cases there cited; Jefferson v. United States, 77 F.Supp. 706 (D. Md., 1948). Even with respect to auto negligence cases the commonlaw "scope of employment" limitation has immunized the Government where a citizen in like circumstances would be liable. E.g., Long v. United States, 78 F.Supp. 35 (S.D. Cal., 1948).

62 "[T] $[\mathrm{T}$ he ancient and discredited doctrine that 'the King can do no wrong' has not been uprooted; it has merely been amended to read, 'the King can do only little wrongs.' " Jackson, J., dissenting in Dalehite v. United States, 346 U.S. 47, 60 (1953).

${ }^{*}$ Consult discussion at note 61 supra. It has been held that a suit for negligence under the Act will not lie if the same facts constitute an actionable intentional tort. Moos v. United States, 118 F.Supp. 275 (D. Minn., 1954), aff'd 225 F.2d 705 (C.A. 8th, 1955). Thus, for example, in the principal German case, since without the patient's consent there 
With respect to the general climate in favor of permitting suits against the sovereign, however, it is significant that in a recent case ${ }^{64}$ the Supreme Court seems to have taken the remedial purpose of the Act as a predicate for increased governmental liability, since this tends to spread the costs of governance among all members of the community. With respect to the federal government's statutory liability for negligence under circumstances which previous cases had held to fall within the "discretionary function" exception, ${ }^{65}$ the Court stated in reversing unanimous lower courts:

Congress was aware that when losses caused by such negligence are charged against the public treasury they are in effect spread among all those who contribute financially to the support of the Government and the resulting burden on each taxpayer is relatively slight. But when the entire burden falls on the injured party it may leave him destitute or grievously harmed. Congress could, and apparently did, decide that this would be unfair when the public as a whole benefits from the services performed by Government employees. And for obvious reasons the United States cannot be equated with a muncipality, which conceivably might be rendered bankrupt if it were subject to liability for the negligence of its firemen. ${ }^{68}$

This passage of the Court's opinion may indicate increasing favor on the Court for increased State responsibility and indicates a more liberal interpretation of the Tort Claims Act's exception to the severe doctrine of sovereign immunity.

When the federal government takes private property, its owner may seek compensation by suit under the Tucker Act, which permits assertion of claims against the United States with respect to express or implied contracts and for claims "founded ... upon the Constitution." when government officers, pursuant to proper authority, ${ }^{68}$ appropriate proper-

was clearly an actionable battery, no claim for malpractice for negligently or unreasonably experimenting on a human being would be within the scope of the Act. Consult Moos v. United States, supra. Moreover, even if it be assumed that the patient had validly consented to the battery, it is unlikely that the malpractice action, although then possible under the Act, would be successful, for such consent would probably constitute assumption of risk. The circumstance of consent, however, makes more probable a recovery under the Tucker Act for an implied contract for compensation. Consult discussion at 528 infra.

* Rayonier, Inc. v. United States, 352 U.S. 315 (1957), rev'g 225 F.2d 642 (C.A. 9th, 1955), which had unanimously affirmed the district court's denial of relief.

${ }^{\infty}$ E.g., Dalehite v. United States, 346 U.S. 47 (1953).

${ }^{\infty}$ Rayonier, Inc. v. United States, 352 U.S. 315, 320 (1957).

or 10 Stat. 612 (1855), as amended, 28 U.S.C.A. $\$ 1346$ (1950): "The district courts shall have original jurisdiction, concurrent with the Court of Claims, of ... [a]ny civil action or claim against the United States . . . founded either on the Constitution, or any act of Congress, or any regulation of an executive department, or upon any express or implied contract with the United States or for liquidated or unliquidated damages in cases not sounding in tort."

"For an example of a "taking" perpetrated without authority consult, e.g., Hooe v. United States, 218 U.S. 322 (1910). 
ty under circumstances which indicate a recognition of the owner's title there is a contractual obligation (implied-in-fact) to compensate. ${ }^{69}$ The Act also makes the government liable for a claim founded upon the Constitution's command that "private property shall not be taken for public use without just compensation" when private property is tortiously taken and retained for the public benefit. ${ }^{70}$ By authorizing such suits under the Fifth Amendment, the Tucker Act has in effect created a "sacrifice" liability. The right of action involved arises from the benefit conferred on the public ("property taken for public use"), and the measure of relief is "the owner's loss, not the taker's gain." "Like the other examples of "sacrifice" discussed earlier, however, the Supreme Court has not always recognized that although unusual circumstances may give immunity for a tortious "taking," where a benefit is conferred on the community the Fifth Amendment requires compensation for the injured party. Thus, in one case the Court denied recovery to the owners of a factory destroyed by the Army because it was thought to house the germs of a contagious disease. ${ }^{72}$ Like a more recent case involving a destruction of property to prevent its falling into the hands of the enemy, ${ }^{73}$ however, this decision may reflect the Court's doubts that a benefit was conferred on the public. ${ }^{74}$ If so, it may be suggested that the Fifth Amendment's words public use should be given a less restrictive interpretation. ${ }^{75}$ The Fifth Amendment's directive that private property shall not be taken without just compensation applies equally, via the Fourteenth Amendment, to the states ${ }^{76}$ and munici-

\footnotetext{
${ }^{\infty}$ Phelps v. United States, 274 U.S. 341, 343 (1926) ("where pursuant to an Act of Congress private property is taken for public use ... the Government is under an implied obligation to make just compensation ... consistent with . . . constitutional duty . . . as well as with common justice"); United States v. Palmer, 128 U.S. 262 (1888) (recovery of value of patent which government was invited by patentee to use); United States v. Great Falls Mfg. Co., 112 U.S. 645 (1884) (appropriation under Act of Congress; title of owner recognized) ; United States v. Russell, 13 Wall. (U.S.) 623 (1871) ("understanding" that owner be compensated).
}

${ }^{5}$ E.g., United States v. Causby, 328 U.S. 256 (1946).

"Ibid., at 261. "[T] que question is what has the owner lost, not what has the taker gained." Holmes, J., in Boston Chamber of Commerce v. Boston, 217 U.S. 189, 195 (1910). Consult McCormick, The Measure of Compensation in Eminent Domain, 17 Minn. L. Rev. 461 (1933); Hale, Value to the Taker in Condemnation Cases, 31 Col. L. Rev. 1 (1931).

"2 Juragua Iron Co. v. United States, 212 U.S. 297 (1909).

${ }^{\pi 3}$ United States v. Caltex, Inc., 344 U.S. 149 (1952).

"The decision seems primarily to rest on other circumstances: "The plaintiff, although an American corporation, doing business in Cuba, was, during the war with Spain, to be deemed an enemy to the United States with respect of its property found . . . in that country, and such property could be regarded as enemy's property. . . ." Juragua Iron Co. v. United States, 212 U.S. 297, 306 (1909).

${ }^{7}$ Compare the German concept of benefit at notes $17-18$ supra.

${ }^{78}$ Chicago, B. \& Q. R. Co. v. Chicago, 166 U.S. 226 (1897) (Fourteenth Amendment requires that states pay compensation to owners of private property taken for public use). 
palities. ${ }^{77}$ It would seem, despite the obstacle of sovereign immunity, ${ }^{78}$ that a party deprived of his property who has exhausted all possibility of state court relief ought to have an action in the federal courts against these governmental units for sacrifice. ${ }^{79}$

In the usual circumstance where the public has benefited from an invasion of one individual's bodily integrity, his right to recover under the Fifth Amendment may rest on whether one can have a "property" in his limbs or health. ${ }^{80} \mathrm{~A}$ woman has been said to have a "property" in the protection of her good name, ${ }^{81}$ in her marital status, ${ }^{82}$ and in her association with her children. ${ }^{83}$ Moreover, a man's labor itself, as well as his right to labor, have

${ }^{77}$ Home Tel. \& Tel. Co. v. Los Angeles, 227 U.S. 278, 294 (1913) (Fourteenth Amendment applies to acts of city officials done under authority of a municipal ordinance).

${ }^{78}$ U.S. Const., Amend. 11, quoted at note 53 supra (states immune from suit by foreign subjects or citizens of other states); Hans v. Louisiana, 190 U.S. I (1890) (state immune from suit by its own citizens).

70 The Supreme Court has long recognized that a state should not be allowed to violate the Fourteenth Amendment and yet enjoy the sovereign immunity of the Eleventh (note 78 supra). When state courts have been unavailable for relief the federal courts have not been unwilling to provide a remedy. E.g., ex parte Young, 209 U.S. 123 (1908). For a detailed discussion of the various distinctions involved in suits against the sovereign consult The Sovereign Immunity of the States: The Doctrine and Some of Its Recent Developments, 40 Minn. L. Rev. 234 (1956) ; Block, Suits Against Government Officers and the Sovereign Immunity Doctrine, 59 Harv. L. Rev. 1060 (1946).

${ }^{80}$ In has been stated that a man has no property in his life since he can make no gift or assignment of it and a creditor cannot take it in payment of a debt. Veith v. Chicago Title \& Trust Co., 307 Ill.App. 99, 108-9, 30 N.E.2d 126, 130 (1940). However, life is a state of being, while the body is an tangible thing.

In another analogous area there are condemnation cases indicating that corpses, slaves, certain personal rights, and even some privileges so intangible as to be incapable of valuation, may not be condemned. See University of Louisville v. Metcalfe, $216 \mathrm{Ky} .339,343$, 287 S.W. 945, 947 (1926) (corpses); Corbin v. Marsh, 2 Duval (Ky.) 193 (1865) (slaves); Traction Co. v. Parish, 67 Ohio St. 181, 65 N.E. 1011 (1902) (consent to release a state-granted immunity). See Albright v. Sussex County, 71 N.J.L. 303, 307, 57 Atl. 398, 400 (1904) (exclusive fishing privilege; "property taken shall be reasonably capable of just estimation"). Consult generally Colvin, Property Which Cannot Be Reached by the Power of Eminent Domain for a Public Use or Purpose, 78 U. of Pa. L. Rev. 1, 137 (1929). But cases holding an item not to be a proper subject of condemnation are not determinative of whether that item is property; money, for example, though all will admit it to be property, cannot be condemned. See Burnett v. City of Sacramento, 12 Cal. 76, 84 (1859) (because money is the very medium of compensation); People v. Mayor of Brooklyn, 4 N.Y. 419, 424 (1851) (because money is subject to exaction by virtue of the power of taxation).

${ }^{81}$ See Niver v. Niver, 200 Misc. 993, 995, 111 N.Y.S.2d 889, 891-92 (1951) (injunctive relief). Similar cases are collected in Availability of Injunctive Relief Under State Civil Rights Acts, 24 U. of Chi. I. Rev. 174, 176 n. 12 (1956).

s2 Ibid.

${ }^{53}$ See Stark v. Hamilton, 149 Ga. 227, 230-31, 99 S.E. 861, 862 (1919) (injunctive relief). Compare May v. Anderson, 345 U.S. 528, 533 (1953) (parent may not be deprived of custody of child- "[r]ights far more precious ... than property rights"-by a proceeding in which personal jurisdiction of the parent is lacking). 
been said to be "property." 84 The rationale of one court in expanding the concept of property in another connection was that "many things are considered property which have no tangible existence, but which are necessary to the satisfactory use and enjoyment of that which is tangible." a citizen is deprived of a part of his body or of his health, and thus of his ability to labor, by a premeditated action which benefits the public in an appreciable manner, the property of that citizen in the products of his labor has been "taken." It would thus seem plausible to conclude that a citizen has "property" in his limbs and in his health, and when deprived of these to confer a benefit on the community, a recovery against the federal government under the Fifth Amendment should ensue.

Even if one can have no property interest in his limbs or health, where an individual is compelled, like the German soldier, to sacrifice one of these for the general welfare he might recover under the Tucker Act for an "implied contract." When circumstances indicate that government officials recognize the title of the owner whose property they take, an implied contract to compensate is found. ${ }^{86}$ The same type of contractual obligation should arise when limbs or health are taken, for whatever interest exists in bodily integrity unquestionably belongs to the individual. ${ }^{87}$ Thus, if the government should use a person without his consent as a "guinea pig" for scientific research, the government should be taken to have promised to pay for any injury which might result. This promise distinguishes the case from the many decisions holding that a plaintiff may not waive a tort and sue in assumpsit under the Tucker Act on a quasi-contractual obligation. ${ }^{88}$ In the case supposed, "to stand on the

s4 "The property which every man has in his own labor, as it is the original foundation of all other property, so it is most sacred and inviolable. The patrimony of the poor man lies in the strength of his own hands; and to hinder him from employing these in what manner he may think proper, is a plain violation of this most sacred property." State v. Goodwill, 33 W.Va. 179, 183 (1889). Consult also Mowrey v. Mowrey, 328 Ill.App. 92, 65 N.E.2d 234 (1946); Jensen v. Sheker, 231 Iowa 240, 1 N.W.2d 262 (1941).

${ }^{85}$ City of Denver v. Bayer, 7 Colo. 113, 115, 2 Pac. 6, 7 (1883), quoted in In re Forsstrom, 44 Ariz. 472, 480, 38 P.2d 878, 882 (1934).

${ }^{s e}$ Authorities cited note 69 supra.

${ }^{87}$ That courts are cognizant of the distinction in immunity cases between "property" rights and "personal" rights, consult Kamau v. County of Hawaii, - Hawaii - , - (1957): "[Y] tet it is a shocking doctrine that no immunity attaches where property rights are violated by governmental action, but immunity does attach where it is a matter of the life or limb of a human being."

${ }^{8 s}$ Bigby v. United States, 188 U.S. 400 (1903) (contract to carry safely cannot be invoked to permit a recovery under the Tucker Act when a citizen is injured by the negligence of an elevator operator employed by the government). "There are few cases ... that cannot be brought under the head of a contract implied in law; and it [is] established that such contracts are not within the jurisdiction of the Court of Claims." Holmes, J., in Alabama v. United States, 282 U.S. 502, 507 (1931). Consult also Yearsley Ross Constr. Co. v. United States, 309 U.S. 18 (1940); Holland-America Lijn v. United States, 254 U.S. 148 (1920); Hickman v. United States, 135 F.Supp. 919 (W.D. La., 1955); United States v. Huff, 165 F.2d 720 (C.A. 5th, 1948) ; United States v. Willis, 141 F.2d 314 (C.A. 4th, 1944); New Rawson Corp. v. United States, 55 F.Supp. 291 (D. Mass., 1943). 
undertaking and to disregard the tort is not to invoke a fictive agreement. It merely recognizes a choice of procedural vindications open to the injured party." 89

When benefit to one is coupled with loss to another, although the tort may be excused, the doctrine of sacrifice requires that the benefited party make good the loss. German law, recognizing no sovereign immunity, has invoked precisely this doctrine in holding the sovereign responsible where its officials have injured an individual in circumstances under which a benefit to the public is reasonably to be expected. In France, sovereign responsibility has achieved a full development through the idea that all activities of the government are beneficial to the public and that the public should therefore compensate for all injuries traceable to those activities. While it has never been recognized as a distinct legal concept, liability for sacrifice exists in American law. Due to a rigorous application of the doctrine of sovereign immunity, however, this liability has not been imposed on the national sovereign except insofar as the Tucker Act allows actions by an owner whose property has been taken for public use without just compensation. There is technical justification for the right of an individual to sue the national government when the public has benefited from a taking of his limbs or health. Failure to grant relief in such a case would be a prime demonstration that it is "idle to give to a party a right without a remedy to enforce it." ${ }^{\circ 0}$ In France and Germany, civil law countries where the judiciary is commonly supposed to possess far less freedom than its common law counterpart, ${ }^{91}$ a recovery quite clearly could be had. It is ironic that the American treasury emits a golden stream to nations which have proved that State responsibility will not exhaust their finances. ${ }^{92}$ The American citizen used as a "guinea pig" to benefit the public should be allowed to assert his claim in a court as of right, rather than being forced to seek whatever relief he may wring from the legislature as a suppliant. ${ }^{93}$

* Frankfurter, J., in Keifer \& Keifer v. R.F.C., 306 U.S. 381, 395 (1939).

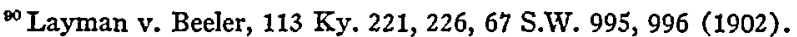

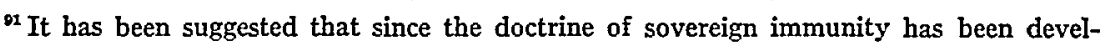
oped by the courts, it is their duty to modify or abandon it. Kamau v. County of Hawaii, - Hawaii - (1957). Consult Cahn, Jurisprudence, 32 N.Y.U. L. Rev. 133, 143 et seq. (1957) ; Green, Freedom of Litigation, 38 IIl. L. Rev. 117 (1943).

92 "Charity begins at home."

os "The rights of the citizen remain the same whether they collide with an individual or the government, and judicial tribunals were wisely established to correct such matters without the individual being relegated to the position of no other remedy except to appeal to a legislature." Boxberger v. State Highway Dept., 126 Colo. 438, 441, 250 P.2d 1007, 1008 (1952). With respect to relief by private bill in the legislature consult Gellhorn and Lauer, Federal Liability for Personal and Property Damage, 29 N.Y.U. L. Rev. 1325, 1327-62 (1954); Gellhorn and Lauer, Congressional Settlement of Tort Claims Against the United States, 55 Col. L. Rev. 1 (1955); Shumate, Tort Claims Against State Governments, 9 Law \& Contemp. Prob. 242, 249 et seq. (1942) ; Pound, Justice According to Law, 14 Col. L. Rev. 1 (1914). 


\title{
APPENDIX
}

\author{
20 BGH 61 (Supreme Court of the West German Federal Republic, Feb. \\ $13,1956) .^{*}$
}

[Plaintiff was wounded during World War II by a grenade explosion and in 1941 was transferred for treatment to the surgical clinic at the University of Heidelberg. At the clinic he was treated for an aneurysm (blood vessel enlargement) which had developed in his right thigh as a consequence of the wound. The doctor to whom his treatment was entrusted took two "artery-graphs" of his leg by injecting a radioactive material called thorotrast, once before and once after performing an operation. Plaintiff sued the State of Baden-Württemberg for the damages he suffered from the use of this radioactive material. The complaint was "based in theory on violation of duty by an official." The District Court in Heidelberg allowed recovery and the State Supreme Court in Karlsruhe affirmed. The State appealed to the Federal Supreme Court (pp. 61-63).]

[p. 63] I. The appellate court affirmed a claim based on sacrifice for the general welfare [Aufopferungsanspruch] primarily for the following reasons: The decision in $9 \mathrm{BGH}$, at p. 83, establishes that with respect to both interferences which rest upon law, and encroachments upon bodily integrity, a claim for an Aufopferungsanspruch may be granted. .. . The financial support, which the plaintiff receives by way of veterans' benefits, especially his pension, does not come close to making him whole for the injuries he has suffered. Under the facts of the case it cannot be claimed that war-connected injuries such as plaintiff has suffered are exclusively governed by the benefit laws. The special kind of treatment given the plaintiff (taking of arterygraphs by use of thorotrast) served a collateral purpose here, namely, scientific research. Through this unusual method of treatment an especial sacrifice was exacted from the plaintiff who was one of the relatively small group of soldiers tansferred to the hospital for this collateral purpose. The patron of scientific research, in whose interest the encroachment which led to plaintiff's injury was carried out, was the University of Heidelberg, to which flowed the advantages derived from the results of scientific work in the clinic, and is thus to be viewed as "enriched" by the encroachment. Therefore the then-subsisting State of Baden, financial supporter of the University of Heidelberg, became bound to indemnify it, and defendant State has taken the place of the State of Baden, as its legal and functional successor.

[p. 64] II. 1. The point of departure of the appellate court, that, pursuant to the legal principle contained in $\$ 75$ Einl ALR [Prussian General Land Law (1794)], claims for sacrifices to the community could be allowed not only with respect to encroachments upon property, or rights rightfully viewed as equivalent to property, but also with respect to interferences with bodily integrity, even when these invasions ensued from measures resting upon legislative enactment, is correct. The Court has set forth this concept of the law with particularity ( $9 \mathrm{BGHZ} 83$ et seq.), and there is no reason to depart from that formulation. It is further correct that the plaintiff, who suffered serious and unfortunate bodily injuries due to his war wound and the hospital treatment which followed, has sacrificed his health for the community. Finally, without doubt, it can also be taken as a fact that the plaintiff finds no full recompense for the financial losses caused by the impairment of his health in the financial aid which he receives within the framework of veterans' benefits.

In general, however, a war-service injury with its consequences presents no case

* Translation and condensation of facts by the University of Chicago Law Review. 
of sacrifice in the legal sense because it lacks the element that, through intervention of higher authority, an especial sacrifice has been demanded of the affected party as an individual or as a member of a delimited group, striking him unequally in comparison to others or not exacted from others. The war service laws demanded quite generally that all able-bodied men should serve in the war and assume the related disadvantages and dangers; hence an individual, if he suffered an injury in the course of fulfilling his war service obligations, made no special sacrifice within the meaning of the general legal principle which finds its expression in $\$ 75$ Einl ALR. ****

[p. 65] Thus the plaintiff can only assert a claim for sacrifice if, independent of the war service injury, a new and independent circumstance of sacrifice can be shown....

According to the appellate court's findings, there was a standing order in the army to transfer soldiers with illnesses like the plaintiff's to the sub-hospital at the university surgical clinic in Heidelberg. This measure was not solely prompted by the thought of making available the special equipment, experience and personnel, which the sub-hospital had at hand, to the ill or wounded soldiers in the exclusive interest of their healing. Rather, according to the determinations of the appellate court, the thought of making available to $\mathrm{Dr}$. $\mathrm{Ph}$. . . the extensive patient-material necessary for his special research work respecting artery-graphs and the use of thorotrast, played a special role. Acquisition of the patients elsewhere would have caused difficulties since the agreement of the patients to the special method of treatment would otherwise have been required. It was not the case that the taking of such artery-graphs of soldiers sent to the Heidelberg clinic constituted a testing upon them as pure guinea-pigs of a method of treatment until then utterly unknown, and otherwise not customary. Nonetheless, the pervading thought was to afford $\mathrm{Dr}$. Ph. [p. 66] extensive opportunity ... to investigate this unusual method of treatment involving the use of a material whose degree of dangerousness had not yet been conclusively established. It was hoped thereby to discredit the doubts raised (in the opinion of $\mathrm{Dr}$. $\mathrm{Ph}$. incorrectly raised) against this method by other scientists. So with respect to the plaintiff, it was not the case that use was made of the "contrast-material" because of the material's special advantages with regard to healing the plaintiff. Much more prominent was the research purpose which stood out in the foreground and gave the picture of the plaintiff's treatment its decisive imprint. Legally, this state of facts is to be judged differently than the cases in which a substance whose attributes have not yet been fully tested has come to be used on an ill or wounded soldier, where the risk involved had to be assumed for lack of other means promising of success, in the interests of achieving a cure which might otherwise not be fully or even partially achieved. In such a case the use of a dangerous substance would be made only in the interest of the sick individual, and it could not be alleged that such a person had been required to make an especial sacrifice in the legal sense, if the use of such material were followed by unfortunate consequences. In such a case the results of the treatment would be attributable solely to the dangerous circumstances into which the affected party, as a soldier, had been placed. The situation is different, however, when, as here, the use of a method of treatment (even if not considered especially dangerous, but still objectively dangerous) is pursued, not solely with the idea of healing the invalid, but with the view toward the collateral research purpose tipping the scales. Here the question relates to the development of a new area of danger, and a new condition of sacrifice has ensued for the affected soldier, who was obliged unquestioningly to be amenable to the arrangements made by his superior medical officers, due to his soldierly duty of obedience . . . and a 
circumstance of sacrifice independent of the war injury entered upon the picture [p. 67]. Therefore, the lower courts correctly granted the plaintiff an equitable recompense for the injuries derived from the thorotrast artery-graphs, upon the theory of sacrifice for the community. In measuring his damages; as plaintiff in his complaint has already suggested, the veterans' compensation paid is to be taken into consideration.

2. The lower courts also correctly assumed that defendant State was liable for plaintiff's claim for sacrifice. The appellate court in this respect argued: It is true that the army was the "encroaching higher authority." That, however, is not decisive; much more important is who "was benefited" from the measures here being considered. It was the University of Heidelberg that was benefited by the treatment of the plaintiff that was undertaken for the sake of the collateral research purpose. Thus the then-existing State, as financial supporter of the University, became liable to pay damages. The defendant State, as the former State's legal and functional successor, stepped into its shoes, and, in effect, became liable. $* * * *$

It becomes decisive, according to the principles announced in $11 \mathrm{BGHZ} 248$, 251 et seq., that in any event the University of Heidelberg, as the proponent of scientific research, must be considered as benefited by the special sacrifice of the plaintiff. The liability of the defendant State follows from that fact. $* * * *$

[With respect to recompense for pain and suffering, the Court concluded that under the Civil Code such damages cannot be allowed as part of the damages granted on the ground of a sacrifice claim (p. 68).]

[p. 69] Moreover, the provisions of $\$ \S 74-75$ Einl ALR, to which the legal principle of sacrifice-claim is traceable even for the regions outside of the former Province of Prussia as a recognized doctrine strongly imbedded in the customary law, proceed from the principle that damages are to be allowed only to the extent of financial injuries. $* * * *$

[I]t must be concluded that the will of the Legislature is that recompense for nonfinancial injuries may be granted only in the special cases expressly ruled by $\$ \S 847$ and 1300 , B.G.B., and that damages and recovery shall remain limited to recoupment of financial injuries even with respect to circumstances of sacrifice. [p. 70] In view of this state of the law it would seem that even if the general sacrifice claim ... has experienced an expansion in the course of legal development ... nonetheless ... that the "equitable recompense" granted should also comprehend recompense for non-financial injuries, is not justified under the law today. True, as this Court suggested in its "vaccination injury decision" (9 BGHZ 83, 89), the worthiness of protection of life and health, and equally of liberty, are today especially emphasized in the legal order. The Constitution, in Article 2, in addition to the right to free development of personality, has expressly guaranteed the right of the individual to life and bodily integrity, and the unassailability of the freedom of the person, as constitutionally protected basic rights. This legal value judgment concerning these facets of life alone, however, according to the conception of this Court, would not yet provide justification for an extension of the general sacrifice-claim in the direction discussed. Rather, it must be left to the Legislature to derive, from the categorization of values of the individual facets of life expressed in the Constitution, . . . inferences for a differently oriented law of damages. $* * * *$

[N]on-financial damages incurred by the plaintiff must therefore be denied him within the context of the legal sacrifice doctrine. However, just as in the general law of damages, amelioration of non-financial loss is not foreclosed, for recovery by way of natural [p. 71] restitution pursuant to $\$ 249$, B.G.B. can be demanded. 
In a proper case, those money outlays may be considered which would enable the plaintiff to alleviate his remaining non-financial loss, especially his bodily suffering and depressions.

\section{RESALE PRICE MAINTENANCE BY AN INTEGRATED FIRM: THE McKESSON \& ROBBINS CASE}

Fair-trade contracts between an integrated manufacturer-wholesaler and competing independent wholesalers were held illegal by the Supreme Court in United States v. McKesson \& Robbins, Inc. ${ }^{1}$ By a literal application of the Miller-Tydings Act, ${ }^{2}$ its exemption from the general law against price fixing ${ }^{3}$ was held not to apply. But the ambiguous position of the integrated manufacturer-at the same time supplier and competitor of the wholesalers with whom he contracts-suggests a more complicated problem than can be solved appropriately by a literal application of the Act.

Under the general law of price fixing, agreements to fix or maintain prices have repeatedly been said to be "illegal per se," without differentiating between whether or not they operate within the same level of distribution. ${ }^{4}$ This failure to differentiate may obscure the fact that the historical objection to "horizontal" price fixing is different from that of "vertical." Cases holding horizontal agreements illegal usually have been concerned with actual or intended market effects, ${ }^{5}$ so much so that in the absence of these determinants

1351 U.S. 305 (1956).

250 Stat. 693 (1937), 15 U.S.C.A. $\$ 1$ (1951), quoted in text at note 15 infra. The McGuire Act, 66 Stat. 632 (1952), 15 U.S.C.A. $\$ 45$ (Supp., 1956), permits state fair-trade legislation binding non-signers.

${ }^{3}$ Price fixing occurs when two or more firms at the same or different levels of distribution determine the price at which a commodity will sell, instead of leaving this determination to the free competitive market. Fair-trade contracts (resale price maintenance) represent a vertical form of price fixing whereby one firm fixes the sales price for another firm at a different level of distribution. Horizontal price fixing occurs between firms on the same level of distribution. For general discussions on resale price maintenance consult: 1 Callmann, Unfair Competition and Trade Marks, c. 6 (1945); Bowman, The Prerequisites and Effects of Resale Price Maintenance, 22 U. of Chi. L. Rev. 825 (1955); Fulda, Resale Price Maintenance, 21 U. of Chi. L. Rev. 175 (1954).

¿E.g., McKesson \& Robbins, Inc. v. United States, 351 U.S. 305, 310 n.9 (1956) ; United States v. Bausch \& Lomb Optical Co., 321 U.S. 707, 720 (1944); United States v. National Ass'n of Real Estate Boards, 339 U.S. 485,489 (1950).

${ }^{8}$ E.g., see United States v. Frankfort Distilleries, Inc., 324 U.S. 293, 296 (1944); KieferStewart Co. v. Joseph E. Seagram \& Sons, Inc., 340 U.S. 211, 213 (1951): "We reaffirm what we said in United States v. Socony-Vacuum Oil Co., 310 U.S. 150, 223: 'Under the Sherman Act a combination formed for the purpose and with the effect of raising, depressing, fixing, pegging, or stabilizing the price of a commodity in interstate or foreign commerce is illegal per se." " Compare Board of Trade of Chicago v. United States, 246 U.S. 231 (1918). Specific circumstances under which price fixing is not illegal per se have already been delineated. United States v. Frankfort Distilleries, supra, at 301-2 (Twenty-first Amendment gives states power to engage in or sanction price fixing on intoxicating liquors.) (Frankfurter, J., concurring). 